\section{Market as Religion: The Dynamics of Business Network in Megachurches}

\author{
Roberto Bazanini ${ }^{\dagger}$ \\ Universidade Paulista - UNIP, São Paulo, São Paulo, Brazil \\ Celso Machado Junior $\Omega$ \\ Faculdades Metropolitanas Unidas - FMU, São Paulo, São Paulo, Brazil
}

\section{ABSTRACT}

Contemporaneously, in market view, the market of symbolic goods of religion is characterized by the pluralism of options that the postmodern individual has to join religious institutions. In this scenerie, it establishes a situation of fierce rivalry for the achievement of competitive advantage. The according exploratory and qualitative research aimed at analyzing the marketing strategies developed by the IURD leaders with their stakeholders in the Solomon's Temple. The results show that in the competitive market of symbolic goods of religion, the magnitude and sumptuousness of megatemples construct a brand image that places the theological concerns of a future life or of salvation in the background, prioritizing practical solutions to everyday problems. The contribution of the research is to explain how the neopentescostal churches reinterpret traditional values of religiosity, by accepting with naturalness what had been rejected by traditional Protestantism and, thus, to consolidate and at the same time to legitimize the new dynamics of the religions that they act with the logic of the market.

Keywords: Megatemples; Market symbolic goods; Stakeholders, Competitive advantage; Power in network.

\section{INTRODUCTION}

Sharply since the ' 80 decade end, with the fall of the Berlin wall and the fast technological development, among other factors, globalization imposes itself as a real process, diverse, full of contradictions, and the theme, in the social sciences, wins right to citizenship (ORTIZ 2006).

In global culture, increasingly, it predominates as logic of market the dissemination of cultural symbolic goods in globally scale for current and potential consumers by the continued expansion of hightech media.

This high tecnological impact causes constant readjustments in the dynamics of the symbolic goods Market in its diferent sectors: sports, tourism, education, religion, among others, seen that in the relations between human beings in the society occur not exclusively in relation to tangible property, but possess symbolic aspects, whose meanings sometimes transcend their material usefulness.
Corresponding author:

† Universidade Paulista - UNIP, São Paulo, São Paulo, Brazil.

E-mail: robertobazanini@bol.com.br

$\Omega$ Faculdades Metropolitanas Unidas - FMU, São Paulo, São Paulo, Brazil.

E-mail: celsomachado1@gmail.com

Received: 07/28/2016.

Revised: 09/12/2016.

Accepted: 04/13/2017.

Published Online: 12/01/2017.

DOI: http://dx.doi.org/10.15728/bbr.2018.15.3.4 
From this line of reasoning, Bourdieu, and Micelli (1987) conceives the existence of religious currency that embracees by one side, the clerics as symbolic goods producers, on the other, the layman's market to which the symbolic products are intended to be consumed.

In Brazil, among the studies that correlate the market of symbolic goods with religious institutions, can highlight Martino (2003) to consider contemporaneously, that religions have two main characteristics: the social bond that generates and the power that guarantees the existence. Also elaborates on the predominance of religious transit nowadays, since the offer of religious goods and services became more and more in the present.

Regarding the market of symbolic goods of religion, Ferrari (2012) conceives the UCKG incorporate the neoliberal vision of the globalized world capitalism to transform religious goods into profitable symbolic goods. In turn, Baptista and Campos (2013) emphasize that, at present, unlike past times, the individual's religion is independent of nationality, territory, tradition, origin or membership, so the religious transit causes disruptions in this market, in which the UCKG leaders build their identity highlighting his doctrinal peculiarities.

The construction of megachurches as stated Rodrigo Franklin, professor of graduate religion of religion from Mackenzie University of Sao Paulo in an interview: "one will If a religion has a temple, the other wants one too (SOUZA, 2016).

Often megachurches are perceivedas having a world ofadvantages over smaller congregations.A megachurch, by widely accepted definition, is a Protestant church that regularly draws a weekly worship attendance of 2,000 or more including adults and children (THUMMA, BIRD 2015).

The term megachurch is the name given to a cluster of very large, mostly Protestant congregations that share several distinctive characteristics. A megachurch is a congregation that has two thousand or more worship attenders in a week. However, size alone is an insufficient characterization of this distinctive religious reality. These churches generally have similar identifiable pattern and share a common set of organizational and leadership dynamics including five basic characteristics:

1. A conservative theological position

2. A charismatic, authoritative senior minister

3. A very active 7 day a week congregational community

4. A multitude of social and outreach ministries

5. A complex differentiated organizational structure

Commonly, the megachurches not only measured by its size, but also by the frequency of at least 2000 participants in a typical week (SIDEBOTHAM, 2015).In 2011, the American missiologist of "Leadership Network" Warren Bird, conceived a study about churches with megachurches capacity around the world. The relationship of megachurches listed by missiologist refers only to Evangelical churches, divided by continents, received help via internet of Christian leaders around the world, and aimed, portray the situation of Evangelicals in each region where there are these megachurches. It is interesting to note that the criterion used by Warren Bird not only uses data from capacity of the temples, but also incorporates reports of average frequency of cults, considering the present in worship, including children. On the list made in the United States more than 1600 churches with megachurches capacity and more than 1000 in other parts of the world, as shown in table 1 .

Particularly, in Brazil, the rise of the megachurches occurred markedly in the 80's, when Evangelical churches began to buy large abandoned cinema halls, with capacity for up 2000 people.

But, only in the '90, emerge religious building as the world Faith Cathedral, seat of the Universal Church of the Kingdom of God, in Rio de Janeiro and, most recently, the Solomon's Temple that reveals the grandeur and pomp par excellence of this venture. 
Table 1. The ten largest megachurches Evangelicals in the world.

\begin{tabular}{|cccc|}
\hline Name & Priest & Localization & Members \\
\hline Yoido Full Gospel & Uninformed & Seoul - South Korea & 230 thousand \\
Deep Cristian Life Ministry & Willian Kumuyi & Lagos - Nigeria & 75 thousand \\
Faith Church & Sando Nemeth & Budapest - Hungary & 60 thousand \\
MisionCarismaticaInternacional & Cesar Castellanos & Bogota- Colombia & 60 thousand \\
PyungkangCheil & Abraham Park Yook-Sik & Seoul - South Korea & 60 thousand \\
Living Faith & David Oyedepo & Lagos - Nigeria & 50 thousand \\
Yeshu Debar & Rajendra B. Lal & Allahabad - India & 50 thousand \\
New Life & S. Joseph & Bombay - India & 50 thousand \\
Nambu Gospel Church & Uninformed & Anyang - South Korea & 50 thousand \\
Catedral Evangelical de Santiago & Eduardo D. Castro & Santiago - Chile & 45 thousand \\
\hline Source: Adapted from Bird and Thumma (2011). & & &
\end{tabular}

In terms of regular retail physical markets, have similarities with modern shopping malls, supermarkets or souvenirs stores. Ruthven (2012) considers that the dispute created by the faithful in the United States a divine supermarket. Perez (2007) discusses the transformation of religion in supermarket of faith, a religious self-service, which called religion " $a$ la carte", relating to fetishism the goods and the rationalization of world.

Paegle (2014) to study the evangelical Brazilian corroborates the findings of Perez (2007) and Ruthven (2012), to dominate commodification of the sacred with the term "McDonaldization" of faith (Ritzer, 1993) and "divine fast food" as metaphors that permeate the contemporary neo-Pentecostal groups.

Thus, in the symbolic market of religion, the commodification of the sacred quest to find values on things, activities and people that go beyond merely the economic value and provide a sense of life that is much more transcendent and profound than simply accumulating wealth and flaunting of consumption, the re-enchantment of the world.

There be, in this perspective, the construction of the Solomon's Temple is a ,symbolic representation building" which seems to rise over the reality of everyday life, guaranteeing him a peculiar accolade, in other words, a socially legitimate standards framework of conduct, meaning and value tomodern life " competitiveness, the products and services presented like a show makes the religion is be guided no longer from the sacred (tremendum misterium), but the current market lawsin which the supply/demand become priorities on the schedules symbolic speech's of each system, therefore, it needs to be managed efficiently before a highly market in which different anthropophagic stakeholders are present.

The search problem is to find answers to the question: How building megachurches favors the advantage of competitive advantage in the networks of symbolic of religious goods market relationships?

According exploratory qualitative research, based on theoretical and critical followers of Salience Model of stakeholders, the research goal is to analyze the importance of these Universal Church of the Kingdom of God (UCKG) megachurche as strategic resource inserted into the competitive market for goods and services and their specific characteristics in the forms of communication, religious content and sociability of the agents.

The contribution of the research is to discuss the relevance of the applicability of the stakeholders' theory in the symbolic market of religion by allowing study the creation of the megachurches as a marketing strategy from the perspective of the competitiveness in interorganizational relationships networks other actors in the same social field and, consequently, the strengthening of the network elements, such as the evangelical 
parliamentary front, the media, the rise of symbolic goods.and establish relations between the capitalist logic and religious doctrine (MITCHELL, AGLE, WOOD, 1997; PHILLIPS, 1997; ROWLEY, 1997, BOURDIEU, 2003; RUTHVEN, THUBRON (2012); BATISTA, CAMPOS, 2013).

Thus, this research from the theoretical point of view, justified the study of the theme by the social meaning construction process between the organizations present in the business networks (EISEHART, 1989; SA VINHAS, HEIDE and JAP, 2012; PAEGLE, 2014; MEDLIN, TÖRNROOS, 2014). In managerial perspective, research on the megachurches helps to understand how leaders of religious organizations deal with the contextual complexity of business networks, and how managers build the ways this complexity appears (HENNEBERG; NAUDÉ; MOUZAS, 2010; ZAHEER, GOZUBUYUK, MILANOV, 2010; CASTELLS, 2011; MARIOTTI, DELBRIDGE, 2012; SMITH, CAMPOS, 2014)

\section{ASPECTS OF POWER IN RELIGIOUS MARKET}

In the end of the ' 70 , in an attempt to systematize the networks studies, Tichy Tushman, and Fombrun (1979) organized the literature around some great dividing approaches: interorganizational relations, organizations and their borders, career patterns and succession, organizational change, project configuration and power processes and policies.

Castells (2011) was the first theorist to use the concept of "network society" and to frame it in global transformations. The network society arises in the context of the passage of a social paradigm in the field of energy was the deciding factor - industrialism - to a new paradigm, in which the decisive factor is the field of information - informationalism (CASTELLS, 2011; CASTELLS, 2004; CARDOSO, CASTELLS 2006). The concept of networks applies to from the moment that identifies agreements between more than one dyad organizations in business (WEGNER; ALIEVI; BEGNIS, 2015).

In this perspective, business networks conceives valuable assets for survival and growth of the organization (SCHOONJANS; CAUWENBERGE; BAUWHEDE, 2013).

The organizational literature power is matter of study on different perspectives, particularly in relation to levels of analysis that can be individual, organizational and in interorganizational (Olsen et al., 2014). In inter-optics, power is the extent to which an actor can influence the meanings of how the other actors involved design and build the emerging field of business (MÖLLER, 2010).

In addition, Rowley (1997) comprises that on the Theory of Social Networks to explain that organizations not simply respond to each stakeholder individually but to the interaction of multiple influences from a range of stakeholders.

A few of the main authors on the stakeholder theory indicate that organizations should consider the relationships among groups that have a stake in the organization's activities and respond to their demands (FREEMAN, 2010; JONES, 1995; WALSH, 2005). Although some authors consider that, the stakeholder theory as a moral guidance to managers (PHILLIPS, FREEMAN, WICK, 2003; HASNAS, 2013), it is also useful to analyze empirical realities (DONALDSON \& PRESTON, 1995).

In the last two decades several works have been published about the entrepreneurial character of religious organizations operating in the market of symbolic goods, which can be highlighted: Chaves (1992); Bazanini (1998), Mariano (1999); Oliveira (2002), Miller (2002); Jadon (2009); Magaldi (2009); Miklos (2012) e Da Silva Moreira (2015).

Chaves (1992) differentiate religion and other spheres. Bazanini (1998) discusses the market dispute for control of the popular imagination between the UCKG and Rede Globo of Television. Mariano (1999) States those religious organizations did not escape the logic 
BBR

15,3

266

of the market and the Roman Catholic Church with reference to meaning's mechanisms proposed by pastors and priests-presenters of TVs' programs. De Oliveira (2002) discusses the professionalization of staff, fundraising, financial support for businesses and Government, attracting believers, Miller (2002) describes the competitive strategies of religious organizations. Jadon (2009) compares the persuasive strategies of the Universal Church of the Kingdom of God in a semiotic perspective. Magaldi (2009) clarifies that the understanding of the reason by which the contemporary human being left to trade freely and began to accumulate, often, getting of a market that wants to be hegemonic, putting even the money as a way of healing and salvation. Miklos (2012) analyzes religious attitudes present in cyberspace to discuss practices such as candles and prayers found in virtual market procedures to achieve faithful potential futures. Da Silva Moreira (2015) asks about the future of religion under the impact of the culture of feeling and aesthetic inflation and possible emancipative potentials of their own religious experience and tries to take some aestheticized future consequences for the religion under the field of aesthetics.

Particularly in relation to the creation of megachurches, Throup (2011) analyzes the symbolic use of the Temple in Jerusalem, with focus on building the Temple in São Paulo, characterizing it as "emblematic mysticism", in which the symbol is emptied of its meaning originally and then reconstituted as the purpose of the organization which makes it; Smith and Campos (2014) discuss critically the creation of megachurches in market terms, Amigo (2014) Solomon's Temple may be related to religion's spaces developed in current megacities. However, none of these works deals with the relationship between the megachurches and the stakeholders.

\subsection{Some details of The Solomon's Temple}

The Solomon's temple, opened in July 31 th 2014 São Paulo's city, attended by politicians, journalists, pastors, faithful and other stakeholders. The dimensions, the artifacts, the functionality and easiness reveal aspects of grandeur and pomp as the religious organization power.

Dimensions: the work lasted 4 years and cost 680 million R\$. It were purchased about 40 buildings at Bras by UCKG. The temple was built on a plot of $35.000 \mathrm{~m}^{2}$ the equivalent of 5 soccer fields; the temple has a capacity of 2000 people, and is considered the country's largest religious space in built-up area, which is 4 times greater than the National Shrine of Aparecida (NSA) in São Paulo. NSA has $23.300 \mathrm{~m}^{2}$ of constructed area, while Solomon's temple has $100.000 \mathrm{~m}^{2}$.

Artifacts: the altar was built in the Ark of the Covenant's shape, where the ten commandments would have been saved, according to the Bible. 100 square meters of stained glass windows were installed above the Golden altar. On the walls there are great-a dollar nineteen-chandeliers of seven arms. The chairs that will accommodate the thousands of faithful were brought from Spain. 10.000 LED lamps were installed on the roof of the main hall. Were it imported from Hebron, in Israel, 40.000 square meters of stones used in the construction and decoration of the temple. In addition, twelve olive trees were imported from Uruguay to play the Mount of Olives.

Feature: the parking lot of the temple hold 2000 parking spaces, and 241 for motorcycle and 200 for bus. In built area, there is still space for 60 apartments of pastors who are there to work in the temple -including one to the head of the Church, Bishop Edir Macedo. At the altar, there is a conveyor belt designed to load the tithes paid by faithful directly to a room-safe.

Aggregates: besides that, there is also a museum called Memorial, in which 12 columns explaining the origin of the 12 tribes of Israel. 


\subsection{Consumption Symbolic goods RELIGIONS}

Historically, the doctrine proposed by Protestant sect of Quakers is the transcendental essence of capitalism' spirit (WEBER, 1967), whose provisions have changed profoundly the organizational dynamics and worldwide by use of methods designed for efficiency, disseminated Taylorism and Fordism model of production.

Since its origins, Protestantism has always been characterized by the spread of the biblical message under different ways: preaching door-to-door, print media, electronic media, meetings in public squares, later in soccer stadiums or on large rented spaces and, more recently, in the creation of megachurches.

In Brazil, the phenomenon of megachurches is associated with the numerical growth of Evangelicals, especially Pentecostals with the political and media visibility which resulted in two factors that have become decisive for the success of the enterprise: the consumer dissatisfaction, the power of tradition, the divine fast food.

Stark and Bainsbridge (2008, p. 27) state that "human beings are seeking what they perceive to be rewards and avoid what they perceive to be costs".In this line of reasoning, when, in a particular religious practice in small and medium-sized churches, the costs in cash offers (tithes), pressure group compliance, obedience to the authorities and external control of morality overcome the desirable, individuals are looking for other places of worship that satisfy.

The process of McDonaldization of symbolic religious goods is designed by Ritzer (1993, p. 1) as a "process in which the principles of the fast-food restaurant will dominate more and more to American society and the rest of the world". In this line of reasoning thought, McDonald's doesn't sell food, but a system or way of life, in line with the view that above products, seeks to sell the ideology of capitalist thinking (STREECK, 2013).

\subsection{CONTEMIPORARY INDIVIDUALISM}

The Post-modernism thermometer that change, stands as a complex transition to a new type of society called for by Lipovetsky hypermodern and, the perspective of the consumer, it can still be described as a society of hyper consumption and contemporary individualism caused the search for quality of life, passion for personality, ecological sensitivity, abandonment of large systems of meaning, cult of participation and expression (LIPOVTSCKI, 2009).

And, in this line, religion, submitting to the aesthetic and the market, is no longer the space controlled by the rules that predict and programming the behavior of individuals. The liturgies are spoken in so far as they offer psychological results, so messages must treat preferably of practical problems or socio religious, in which the leader indicates the best way of dressing, in which follower must vote in the elections, like owning an armored wedding etc. As a result of these changes arose different groups of stakeholders that are representative elements in the marketing of products and services.

Individualization and release growing stage of the weight of tradition resulted in the "juvenilisation process" in the most different sectors of human activity. Bergler (2012, p. 4) conceives this cultural phenomenon as a "process by which the beliefs, practices, and the religious features teenagers become accepted as appropriate for Christians of all ages ".Thus, the cultural youth pass codes to predominate as script inside which religious worship must happen, like for instance in a mass show priest Marcelo Rossi, or a cult Church 
BBR

15,3

Resurrection in Cristo, in a parade kind March for Jesus or even on popular religiosity Evangelical practiced in everyday life happen.

\section{THEORETICAL REFERENCES}

For the purposes of this article, the theoretical framework applied includes social networking, stakeholder approach and market vision of the religious enterprise.

\subsection{Social NETWORKS}

In designing Sa Vinhas; Heide and Jap (2012), the main purpose of the network is to bring together attributes that allow for adaptation to the competitive environment, supported by uniformed actions, but decentralized, which allows gains to the agents involved. Partnerships take their forms in an attempt to reduce the vulnerability of agents that recognize their limitations to act alone (ANCONA et al., 2007; CHASSAGNON, 2012) and to increase their bargaining power and firm position in the market relative to its competitors (MARIOTTI ;DELBRIDGE, 2012).

For the purposes of this research, power in the network can understand as the ability to alter, destroy, and at the same time build to reality, in that place individuals and groups compared.

The term power refers to relations between partners, understanding the term not as a game system, but only a set of actions that induce and respond to each other (FOUCAULT (1982, p.782). Translated by the authors.

That perspective, the power is not as absolute or as the ability of one person over another, but a set of controls on individuals' devices seeking their subjection.

Bourdieuand Micelli (1987) conceives the cultural field as a symbolic exchange market, once again working along the lines of the law of supply and demand, according to the specificities of the agents involved.

On the one hand, from the point of view of the receiver of the message, the sign and not the object is consumed through the brands that are presented; on the other, the producer market, the competition factor becomes a zero-sum game, in other words, the gain of a given agent tends to represent losses for the other, as shown in table 2.

Table 2. Factors in symbolic goods market.

1. All organizations of symbolic goods are in constant struggle for the conquest of the consumer's mind;

2. What an organization gains in membership represents losses to other competitors;

3. How the behavior of the consumer of those goods tends to irrationality, it is quite common to use subliminal techniques;

4. By virtue of the very cannibalism of the market, often the option to extinguish the competition is the only way to survival. Source: Bazanini (2005, p. 179).

These four competitive factors are present in network relationships' markets of symbolic goods: religious, cultural, sporting, etc. So, the stakeholder theory becomes suitable for analyzing the dynamics of the characteristics of this market.

\subsection{Approach of Stakeholders}

The term stakeholder appeared in 1963 in an internal memo of the Stanford Research Institute and referred to "groups that without your support the Organization would cease to exist” (FREEMAN; REED, 1983, p. 89). 
The conception that is based this reality vision organizational can be summarized in the idea, according to which, besides the shareholders (and / or owners), the organization also is responsible for other groups that have interests in the actions of the organization.

From this vision, two basic definitions about stakeholders are proposed: a spacious one and more strict different one. The first one affirms that stakeholder is any group or individual whom it influences or receives influences by the reach of the objectives of the organization; the second, one tells to individuals or groups that the organization depends for his survival.

The most spacious definition, the idea of which stakeholder it influences or is influenced by the action of other more agents is adopted by many authors like classic and it serves as a starting point for his analyses or criticism (DONALDSON; PRESTON, 1995; MITCHELL, AGLE, WOOD, 1997; FREEMAN, WICKS, PARMAR, MCVEA, 2004; PHILLIPS, 1997; PHILLIPS; FREEMAN; WICKS, 2003).

Among these authors, for the purposes the present article they will be employed the Salience Model Stakeholder (Mitchel, Agle and Wood, 1997) accompanied by the concepts of stakeholder normative, stakeholder derivative and not stakeholders proposed by Phillips (1997).

From this theoretical framework, this study aims to address the stakeholder theory as a way for an organization to remain competitive in a market where there is competition between groups (GOMES-CASSERES, 1994). That is, part of it considers that one central agent of a network that deals better with its stakeholders and can manage them more smoothly, is one that has higher competitiveness in a competition involving a perspective between groups.

Considering then that competition for symbolic goods covers a competition not only between churches, but of all those stakeholders involved in the activities of these churches. In this perspective, churches are necessarily dependent on its stakeholders to maintain its operation in the symbolic goods market. Thus, comprises up such that the competitiveness of churches can be best analysis when there is a prospect of competition between groups and not between isolated churches.

\subsubsection{The Salience Model's Perspective}

The projection model proposed by Mitchell, Agle and Wood (1997) seems to be interesting to understand the competition between groups. The Salience Model, in which they defined that it, is necessary to classify the stakeholders in terms of power, legitimacy and urgency. This criterion of differentiation of the groups of stakeholders allows to establish priorities and define which interests will be attended. This perspective is an interesting way to identify as a central agent deals with its stakeholders in different dimensions and how that stakeholder management can make your group has stronger and cooperative relations, which is the strongest group for a competition market (in this case symbolic goods market). Briefly, the power is defined by the skill of the transmitter to take someone doing something that he would not do without being asked; the legitimacy as the generalized perception of which the actions of an entity are desirable or appropriated, in accordance with the socially built context and the urgency indicating the immediate action necessity that determines the time of answer of the organization as for the stakeholders' solicitations.

Phillips (1997) does countless criticism to Salience Model while pointing to the problematics of reference for the groups in spite of being able with which moral obligations have not been, but that can influence in significant way the organization, like a group not legitimate. Since, it is not possible to differentiate in the categorical form the attributes of legitimacy and power while conceiving that there is only legitimacy, when the power is only a road to acquire it. 
BBR

15,3

With the intention of resolving this impasse, the author then suggests a distinction between legitimacy of the normative stakeholder and legitimacy of the derivative stakeholder to supply a position to the discussion "spacious perspective versus perspective strict" which recognizes simultaneously the moral obligations of the organizations regarding some groups of stakeholders and the pragmatic legitimacy based on the power, predominant of the theory of the organizations.

Therefore, the regulatory stakeholders are defined how "those to whom the organization has a moral obligation, an obligation to equity among stakeholders, higher that due to other social actors. (PHILLIPS 1997, p.173).

Derivatives stakeholders are defined as "those groups whose actions and claims should be taken into account by managers because of its potential effect on the organization and its regulatory stakeholders" (PHILLIPS 1997, p.174). Accordingly In this perspective, the legitimacy of these groups is their ability to influence the organization and its regulatory stakeholders, its legitimacy derives not from themselves, but of their potential influence. Therefore, there is no moral obligation on the part of the organization to worry about your well-being and may be processed only in instrumental form (D'ORAZIO, 2006).

Non-stakeholders are defined as groups or individuals in relation to which the organization does not have any moral obligation and the likelihood of them have an impact on the organization or its legitimate stakeholders is very small. Inspired for these ideas, Philips (1997) proposed a map of the stakeholders as figure 1.

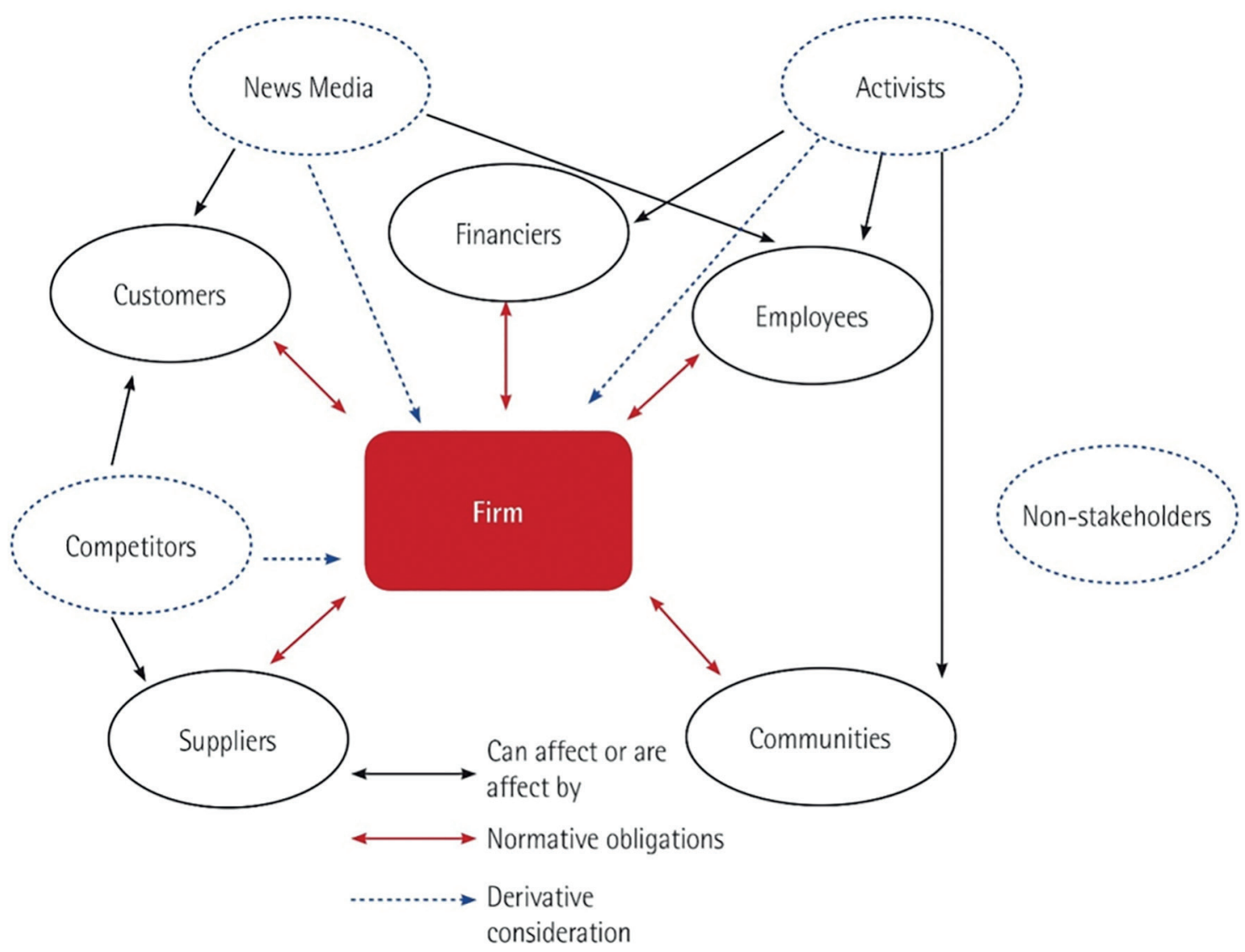

Source: Philips (1997).

Figure 1. Map of the stakeholders: normative, derivative and - non- stakeholder. 


\subsection{THE MARKET VISION OF THE RELIGIOUS ENTERPRISE}

Comparatively the private enterprises the religious organization started to act also in

a market situation as Berger and Luckmann (2004) explains while describing the key characteristic one of all situation complex that it promotes the impossibility of the religious ex-monopolies to be able to count on his public, in other words, the submission started to be a volunteer and, thus, there is no any more the confidence of the loyalty of his members as it had taken place in the past in the religious tradition.

Pursuant to, which before it was imposed by the authority - is government or ecclesial - it started to receive influences of the market religious, just like message, a consumption good needs to be sold in a competitor market to customers who are not more exclusive and who must be convinced buying goods and services of a determined brand.

In Brazil, an important landmark in the market of symbolic goods of the religion took place in 2003, with the promulgation of the Brazilian law n. 10. 8252, which defines the religious organizations and the political parties like legal entities of private right, which deceives freedom in order that to get organize themselves independently of the public power.

As result, the religious organizations are considered since then, like a different being structure of the associations, becoming an own legal being, with autonomy and total freedom in its internal, documentary and structural organization, like private enterprise.

1. Groups that compose the organization or that have interests in risk.

2. Approach the relation between organization and society.

3. It has dimension normative-ethical

Thus, the approach of the stakeholders becomes relevant to analyze the market of symbolic goods of the religion, the laws of the business competition and the capitalist logic each time more submitted to the production of goods and services in which the megachurches represent the vigor and might of the undertaking.

\section{METHODOLOGY}

According exploratory inquiry of a qualitative nature, the objective of the inquiry is in analyzing the importance of these megachurches for the Universal Church of the Kingdom of God (UCKG) as enterprise inserted in the competitor of goods and religious services for the reach of advantage competitive.

The present study is therefore a multiple case study in which conceives three networks for analysis. This type of study has proved the most suitable because to establish an inter-case analysis can understand the differences between them and from that seek to understand which elements seem to justify the competitiveness gap (from the perspective of stakeholders) as advocates Yin (2015).

The sample was composed by three professionals of marketing who act also like serviceable of media training (M1, M2 e M3) for evangelical religious organizations e three faithful (F1, F2, F3) each of the churches, three pastors (P1, P2, P3) and two members of the evangelical parliamentary front (B1, B2).

\subsection{The DATA COLLECTION}

Whereas the methodological research aim was to capture categories from field data, we used the categorization by open grill, since it is a subject in which the theory of churches as business can be limiting to encompass a complete categorization. Therefore, the categorization has manually from the repetition of key elements that could justify the 
BBR

15,3

272

relationship between the characteristics of megachurches and its competitiveness in the symbolic goods market. That is, to seek the theoretical contribution that this study aims, decided to go beyond pattern matching with the theory (EISENHARDT, 1989) and seek new elements that could emerge from the field data.

From this, few were prepared starting questions. The projection only to ensure that key points of the structure of a megachurches and its network in competitiveness from the perspective of stakeholders. Thereby, the researchers acted only as inducers of relevant issues from the very speech of respondents.

Thus, from the perspective of Pressman (1995) and Zanlorenci (1999) are closed, in which the interviewer performs a predetermined set of questions his interlocutor, or open, in which the needs and knowledge of application domain are discussed openly, without a pre-defined set of questions. It is suggested that the analyst to start making context free questions, as table 3 .

Table 3. Questions of the Inquiry.

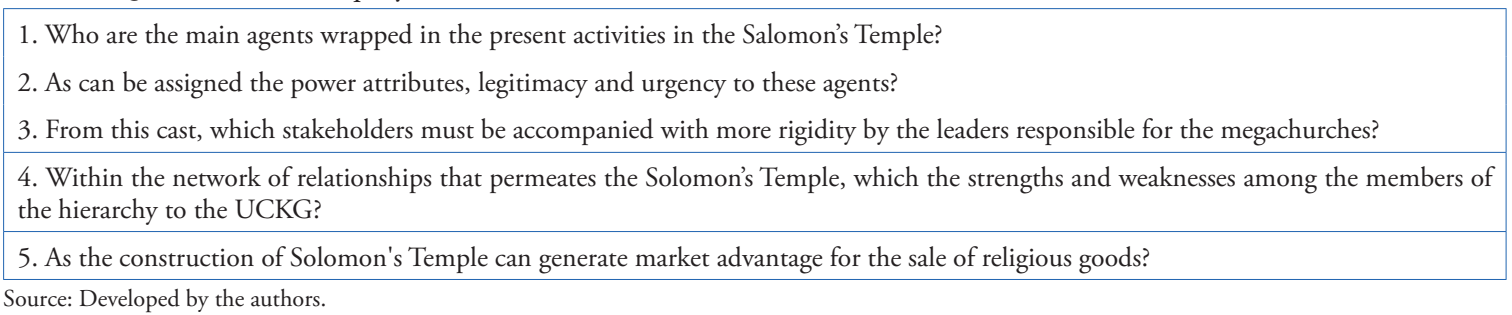

The questions were adapted to the qualification model originally proposed by Zanlorenci (1999). This networks relationships model has two blocks of information: the stakeholder and the requirement. The environment or application domain is the part of the context in which the facts and phenomena occur. The scope of environmental boundary is determined by the setting of objectives and problem focus on study.

The stakeholder is the constituent body which information, interacts with the environment and express their views on issues, defines the requirements and criteria the requirements.

The problem is an element that is part of the environment. The nature of the problem is human origin. Moreover, under this approach, there is only from the perspective of human senses in perception of the facts and environmental phenomena that are not in tune with the will and want the person in the context to which it is related.

The technique to analyze the collection data and interpretation of the results will occur by means of inter cases analysis. Initially, they will be separated in categories analyzed and present descriptively and later interpretive mode, based on the literature on procedure of stakeholders in social networks.

The observation technique nonparticipating allowed the face to face meeting between observer and observed in which data collection process takes place in their own natural environment of life observed that are seen no more as research objects, but as subjects interacting in a given study design (LAKATOS and MARCONI, 2007). In addition, the field diary, led to the construction of the recording of observed facts as an opportunity for the researcher to contact the many and varied meanings present in the views they have of social reality.

\section{RESULTS}

In networks with predominantly anthropophagic characteristics, the competitiveness of a network depends on group characteristics, the size of the organizations and institutions of the growth process, that is, each company will be competitive according to how the group structure and the role played by each company within the group (GOMES-CASSERES, 1994). 
In the perception of interviews, the network relationships symbolic goods of religion, the stakeholders' performance manifest cooperation and conflict, reason why the network include uncertainty, variability, asymmetry; living with the cooperation efforts (TICHY, TUSHMAN, FOMBRUN, 1979; NOHRIA and ECCLES, 1992; GULATI, 1999; GRANOVETTER, 2006) and the inclusion of power, legitimacy and urgency allows greater understanding of the phenomenon, it covers conflicts of interest and games for strategic positions.

The results of the survey, the perception of respondents indicate that the construction of megachurches provides competitive advantage if the stakeholders are identified and continuously monitored as a result of the attributes of power, legitimacy and urgency that they have, as shown in table 4.

Table 4. Stakeholders' attributes and classification.

\begin{tabular}{|ccccc|}
\hline Colunas 1 & Colunas 2 & Colunas 3 & Colunas 4 & Colunas 5 \\
\hline Stakeholders & Power & Legitimacy & Urgency & Classification \\
\hline Federal Government & $\mathrm{X}$ & $\mathrm{X}$ & $\mathrm{X}$ & Definitive Stakeholder \\
Evangelical parliamentary front & $\mathrm{X}$ & $\mathrm{X}$ & $\mathrm{X}$ & Definitive stakeholder \\
Hierarchy Members & $\mathrm{X}$ & $\mathrm{X}$ & $\mathrm{X}$ & Definitive Stakeholder \\
Allied media & & $\mathrm{X}$ & $\mathrm{X}$ & Arbitrary stakeholder \\
Opponent media & $\mathrm{X}$ & & $\mathrm{X}$ & Dangerous stakeholder \\
Concurrent/dectrators & $\mathrm{X}$ & & $\mathrm{X}$ & Dangerous stakeholder \\
Former allies competitors & $\mathrm{X}$ & $\mathrm{X}$ & & Dangerous stakeholder \\
Faithful & & & & Dependent Stakeholder \\
\hline
\end{tabular}

Source: Developed by the authors based on Mitchell, Agle \& Wood (1997).

The interview indicate that network relationships in market symbolic goods of religion, the main stakeholders are the Federal Government and the authorities for the coercive power that can exercise, the leaders of the temple, the Evangelical parliamentary front for supporting the ideology of the church, in the Salience Model perspective are possessors of power, legitimacy and urgency. The media and competitors should just be monitored by virtue of have two of three attributes. However, when that competitor openly takes the detractor position, in the other words, radical critics of the market of religious practices when considering the creation and activities marketing present in megachurches as decay of reflection of Christian values in a world corrupted by worldly customs.

According to Philips (1997) regarding the aspects of stakeholders normative, stakeholders derivatives and not stakeholders, regarding the market of symbolic goods of the religion, it is possible to characterize the aspects of power, legitimacy and urgency in the figure 2.

With reference to the relations of the religious organization with the resulting stakeholders of the attributes of power, legitimacy and urgency (Mitchell, Agle and Wood, 1997) and differentiation between normative stakeholders and derivatives stakeholders, (PHILLIPS, 1997) can develop the matrix of these relationships,

Over the 39 years of its history, the UCKG is facing external attack coming from new neo-Pentecostal movements that imitate. The new movements that have arisen from the UCKG are defined by their own experiences, differences ranging from liturgy to the target audience. The competitiveness of UCKG leaders in Solomon's temple has distinguishing characteristics in relation to detractors deemed hazardous stakeholders, as they use similar procedures in the form (simple and direct message, continuous persuasion of the faithful through the media. However, different in their content as table 5.

Interestingly observer in the table above the similarities between the elements employed by organizations as a competitive factor (simple and direct message, persuasion of the faithful and loyalty). However, the contents are different in their applicability. 

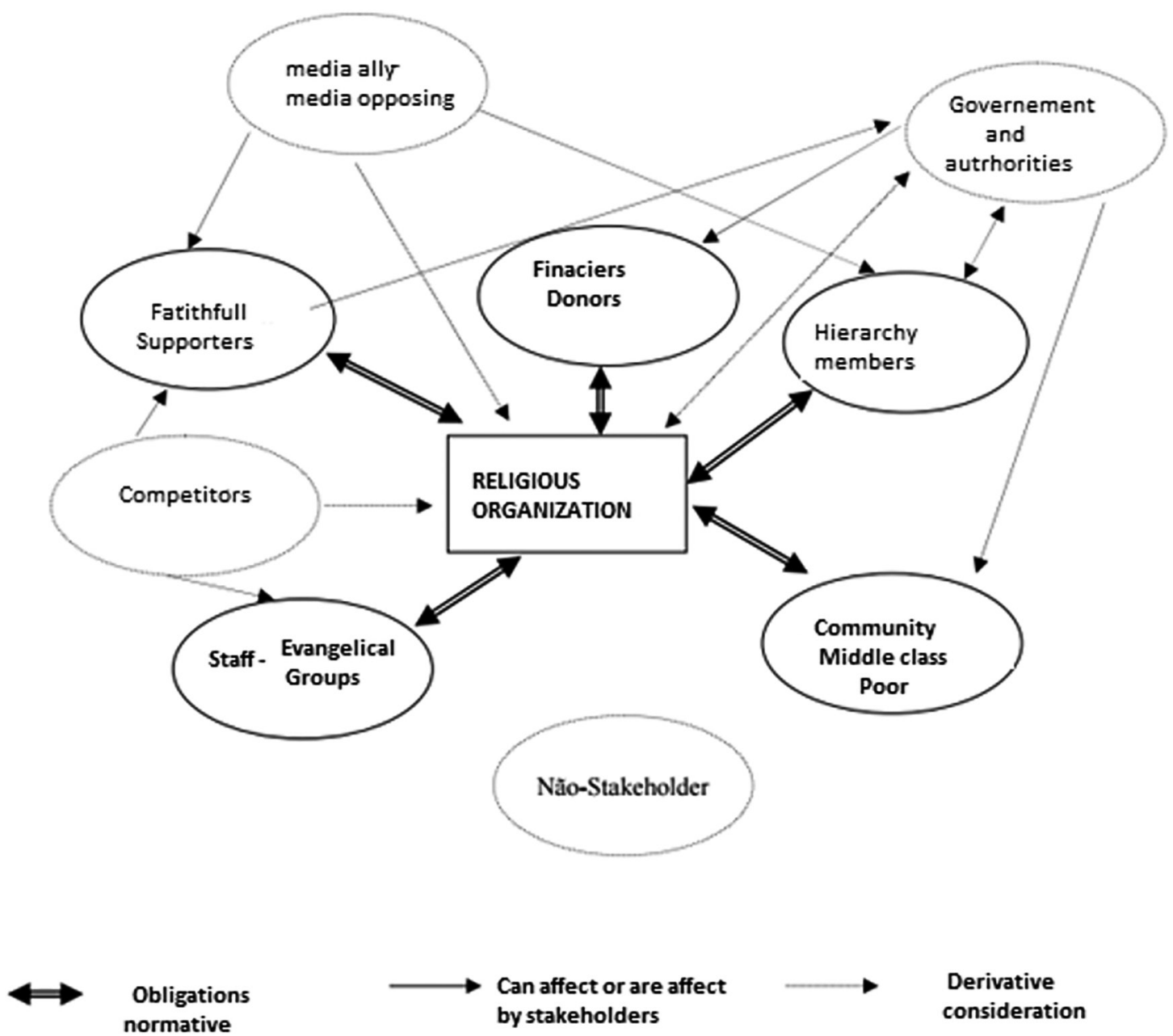

Source: Developed by authors based on Philips (1997).

Figure 2. Stakeholders of the religious organizations.

Table 5. Competitiveness of the UCKG in relation to detractors.

\begin{tabular}{|c|c|c|c|c|}
\hline $\begin{array}{l}\text { Competitiveness } \\
\text { factor }\end{array}$ & $\begin{array}{l}\text { UCKG (Universal Church } \\
\text { of the Kingdom of God) }\end{array}$ & $\begin{array}{l}\text { WCGP (World Church of } \\
\text { God's Power) }\end{array}$ & $\begin{array}{l}\text { IGGC (International Grace } \\
\text { of God Church) }\end{array}$ & $\begin{array}{l}\text { RCC (Reborn in Christ } \\
\text { Church) }\end{array}$ \\
\hline $\begin{array}{l}\text { Simple and direct } \\
\text { message }\end{array}$ & $\begin{array}{l}\text { Use of symbols, } \\
\text { superstitions and fears, } \\
\text { based on the slogan "stop } \\
\text { suffering" and the supposed } \\
\text { victory over the spirits that } \\
\text { produce misery }\end{array}$ & $\begin{array}{l}\text { Posture hick and loaded } \\
\text { language of popular } \\
\text { expressions, Divine healing } \\
\text { is one of the attractive and } \\
\text { gateway to hundreds }\end{array}$ & $\begin{array}{l}\text { In worship services, it is } \\
\text { ordered that the faithful } \\
\text { put their hands on their } \\
\text { heads and determine divine } \\
\text { healing. }\end{array}$ & $\begin{array}{c}\text { Authoritarian and } \\
\text { aggressive language with } \\
\text { expressions of nuances of } \\
\text { physical force }\end{array}$ \\
\hline $\begin{array}{l}\text { Persuasion of the } \\
\text { faithful }\end{array}$ & $\begin{array}{c}\text { Instead of physical } \\
\text { sacrifices, financial sacrifices }\end{array}$ & $\begin{array}{l}\text { Obedience and absolute } \\
\text { passivity of audience }\end{array}$ & $\begin{array}{l}\text { Motivation to be politically } \\
\text { correct as witness of life }\end{array}$ & $\begin{array}{c}\text { Songs, dances and parties } \\
\text { divine }\end{array}$ \\
\hline Loyalty & $\begin{array}{l}\text { Prosperity Way. Dream of } \\
\text { became boss }\end{array}$ & Instant divine healing & $\begin{array}{l}\text { Life in grace with physical } \\
\text { health and prosperity }\end{array}$ & $\begin{array}{l}\text { Hapiness of being young } \\
\text { and determined on the } \\
\text { spiritual path }\end{array}$ \\
\hline
\end{tabular}

Fonte: Desenvolvido pelos autores. 


\section{DISCUSSIONS OF THE RESULTS}

This article was proposed to analyze the power relationships in networks arising from the activities of stakeholders in Solomon's Temple. The analysis was related to the tripod: social networking, stakeholder approach and markets assumptions of symbolic goods of religion.

The Interorganizational networks should not be understood as static structures, as they are characterized by several stages of formation and development (RING and VAN VEN, 1994) and by different forms of structure and governance (PROVAN and KENIS, 2008). Networks, on the understanding Ahuja, Soda and Zaheer (2011), can take different configurations in practice, depending on their network characteristics and because of the need to respond to their transformation. In relation to power, Foucault (1982) substantiates the idea that power in the networks it operates from the perspective of articulation of different interests is realized from actions taken by the actors for mutual empowerment.

It is observed in contrast, that this line of reasoning that the power is not can be conceived as absolute or as a domain of one person over another, but as a set of controls on individuals devices seeking their subjection.

Theorists of stakeholder approach they talk about the kinds of attention that the organization must allocate to the agents involved in social networking. According to Donaldson and Preston (1995) Stakeholders are persons or groups of persons with legitimate interests in the processes or the impact of the company's activities, which does not imply the theory does not imply equal treatment to all stakeholders, hence the importance of identifying them. at least the most relevant, such as Consumers, or if They are nearer to other authors' analyzes Mitchell, Agle, Wood (1997), Frooman (1999) who understand que companies prioritize between stakeholders, and may even negate the impact or demand of one of Them with more attributes of power, legitimacy and urgency.

In marketing terms, the basis for excellent power derives not only from the material and cultural wealth, but the ability of these have in turn it into social and symbolic capital (BOURDIEU, 2003). Symbolic capital is a gift given to those who have legitimacy to impose categories of thought and therefore a world view that promotes the dissemination of religious goods (material and symbolic), to propagate a particular world view that attach meaning to goods and services marketed in megachurches designed as shopping centers of faith.

In relation group versus group present in the internal relationships of the reins organizations compete not just for resources and customers, but for political power and institutional legitimacy, as well as to achieve good social and economical (DIMAGGIO; POWELL, 1983 MITCHELL, AGLE \& WOOD 1997, MOLLER, 2010). The relationships can become mutable and ephemeral duo mainly to the actions of stakeholders high interest and great influence (members of the hierarchy, evangelical parliamentary front and detractors) who work both in operational and managerial levels as effective strategy tool.

In marketing terms, the construction of megachurches in line with the beliefs, habits and religious practices of the Brazilian allows knowledge to turn into business opportunity together with other stakeholders (BOURDIEU, 2003 CAMPOS, 2014), as categories that can be drawn of this research, as table 6 .

These categories highlight the neoliberal vision in building megachurches, environment in which religious goods are transformed into profitable symbolic goods she creation of meanings in social networks (MEDLIN; TÖRNROOS, 2014) by the ability of the Universal Church leaders (bishops and pastors) influence the meanings for the other agents involved (MOLLER, 2010), hence they are considered definitive stakeholders. 
Table 6. Inter cases analysis.

\begin{tabular}{|c|c|c|c|c|}
\hline Categories & UCKG & WCGP & IGGC & $\mathrm{RCC}$ \\
\hline Origins and styles & pioneering & UCKG' style & UCKG'different style & $\begin{array}{l}\text { UCKG' very different } \\
\text { style }\end{array}$ \\
\hline Network power & Referential & Imitative & Distinctive & Innovator \\
\hline Megachurches & Magnificence & Grandiose & Construction & Does not have \\
\hline $\begin{array}{l}\text { Tangible symbolic } \\
\text { goods sales }\end{array}$ & $\begin{array}{c}\text { All artifacts (scarves, oil } \\
\text { swords, pens) }\end{array}$ & Bible, scarves, Oils & $\begin{array}{l}\text { Bible, educational books, } \\
\text { movies, CDs }\end{array}$ & Bible, spiritual retreats \\
\hline $\begin{array}{l}\text { Relations with } \\
\text { opponent Media }\end{array}$ & $\begin{array}{l}\text { Continuous fighting, } \\
\text { sharply against the Globo } \\
\text { Television }\end{array}$ & $\begin{array}{l}\text { Sporadic fighting popular } \\
\text { television presenters }\end{array}$ & $\begin{array}{l}\text { One neutrality, which } \\
\text { depends on the space } \\
\text { purchase in TV }\end{array}$ & $\begin{array}{l}\text { They remain, in a way, } \\
\text { far from the opponents }\end{array}$ \\
\hline
\end{tabular}

Source: Developed by the authors.

The categories referenced in inter cases analyzes allow design lines of reasoning integrators assumptions of integrated social networks to approach stakeholders and market aspects, Rowley (1997) states that the companies do not respond to each stakeholder individually but respond to the interaction of multiple influences of these groups. Therefore, understanding how organizations respond to its stakeholders requires an analysis of multiple and interdependent relationships of those groups, as Table 7.

Table 7. Management of stakeholders.

\begin{tabular}{|c|c|c|c|}
\hline $\begin{array}{l}\text { Religion } \\
\text { Organization }\end{array}$ & Power & Legitimacy & Urgency \\
\hline UCKG & $\begin{array}{l}\text { Alliance with the federal government } \\
\text { Election of deputies and senators }\end{array}$ & $\begin{array}{l}\text { Communication vehicles } \\
\text { Detraction of the opposing media }\end{array}$ & Mobilization capacity of the faithful \\
\hline WCGP & Election of deputies and senators & $\begin{array}{l}\text { Communication vehicles and } \\
\text { detraction of the opposing media }\end{array}$ & Mobilization capacity of the faithful \\
\hline IGGC & $\begin{array}{l}\text { Alliance with the federal government } \\
\text { Election of deputies and senators }\end{array}$ & Communication vehicles & $\begin{array}{l}\text { Ability to be served immediately on } \\
\text { the financial contributions by the } \\
\text { faithful, called "sponsors" }\end{array}$ \\
\hline RCC & $\begin{array}{c}\text { Coordinating the annual "March for } \\
\text { Jesus" since } 1993 .\end{array}$ & Communication vehicles & Mobilization capacity of the faithful. \\
\hline
\end{tabular}

The Building megachurches by neo-Pentecostal religious organizations shows that the way in which the stakeholders are managed provides cohesion to act together with the other competitors.

The UCKG with stable relations with the federal government (definitive stakeholders) and the Evangelical parliamentary front (definitive stakeholders) with vehicles owned and leased communications to maintain competitive advantage, on the one hand, should continue through their leaders impinge competitors direct, since this cannibalistic market, monitor and, in many cases, eliminate competition is the only way to maintain your position. On the other, the ability to mobilize the faithful is an essential factor to strengthen the attributes of power and organization's legitimacy.

Then the competiveness in the symbolic goods of religion relationship market indicates that the pioneering style of the UCKG is reference necessarily imitated by the competition, since the most distant churches of this imitation are those with fewer faithful.

It follows, therefore, the imitative power of the WCGP, closest competitor UCKG in number of believers, while those with distinctive and innovative character do not reach the levels of the first two.

In this sense, the imitative nature of competition is also present in the construction of megachurches. It is evident that the detractors, the RCC does not have megachurches, 
being the least representative in number of believers while the IGGC with its temple under construction, felt the need to imitate the leading organizations in this segment, the UCKG and the WCGP.

Regarding the sale of symbolic goods, the UCKG is paradigmatic model to offer to the market practically numerous goods and services, while other organizations are restricted only to some of these goods, and the RCC for not having megachurch restricts spiritual retreats for young audiences. As lacking megachurches, the annual "March for Jesus", coordinated by RCC since 1993 in Brazil, the visibility and impact before the public, is representative element of power and legitimacy of this religious organization.

Accordingly, so how aggregator event especially in the Pentecostal and neo-Pentecostal denominations, the March for Jesus is an international event and interdenominational conducted jointly by various denominations held annually (the same day) for thousands cities in the world.

Coping relations with the opposing media show that the more powerful is the organization that attacks, most seem to be the strength of the religious organization. Commonly, the UCKG is placed pejoratively in the news of TV Globo, the WCGP faces resistance from popular programs, while IGGC and RCC are designed negatively by the media and sporadically.

Religious organizations necessarily tend to adapt to the dictates of the social context, as religions do not have a timeless essence, therefore, can only be understood from cultural values of contexts through which individuals negotiate a definition and experience of sacred.

The Christianity that was practiced in Europe of the 6thcentury it was not the same of the century 1 st or 2 nd, not even the same of the century 10 st or 15 th the same of previous periods. It is enough to compare several phases of the Christianity from the apostle Paul who was affirming: "I became of Greek to convert the Greeks and became of Jew to convert the Jews", passing for Constantine, Roman emperor who gave freedom of worship to the Christians, up to the alliances done between State and Church during the centuries.

Therefore, one cannot dissociate the notion of God of historical events, since the religious message changes according to the needs of individuals and the community follow a trend of secular sphere without giving up the sacred as guiding principle and mediator.

In this line of reasoning, the Temple of Solomon is the image of greatness that the UCKG's leaders want to project on the church, which for nearly a decade has been relatively overshadowed by other religious denominations as The World Church of the Power of God and the Church International Grace of God.

With this image of grandeur and strength, the activities in megachurch seek both to attract new members and bring back the faithful who turned away in an attempt to enhance the image of an organization chosen by God, successful and holds capable of symbolic power bring success and power to his followers.

In this market, contemporaneously, the megachurches are related in power with religious agencies emphasize prosperity as legitimate human rights that are claimed matter of urgency, which is why the megachurches seek to attract people through the belief that certain religious leaders stand out because they are chosen by God. In this sense, the great temples attract advertising, image, increasing the number of faithful and hence competitive advantage over the intense competition in the symbolic of religious goods market.

It is interesting to note that both the market religion supporters and detractors can be legitimated by biblical passages. In the first case first Corinthians 13, in the second, Acts 17:24).

Finally, in synthesis, according Zaheer, Gözübüyük and Milanov (2010) the exclusion of power, legitimacy and urgency in research on networks creates a gap of understanding, since it is virtually impossible understand the movements of relationships that confront cooperative actions with actions individual interests. Even when the subject appears, power, 
BBR

15,3

278

legitimacy and urgency are placed as variables. Alongside other and not as an ordering principle. Consequently, we can say that the practices of the religion of market all that of his detractors they can be justified in biblical precepts, reason by which, in the market of symbolic goods of the religion, the speeches of hierarchy members, an Evangelical parliamentary front e the detractors a must be continuously monitored.

\section{FINAL CONSIDERATIONS}

The proposal to examine the possibility megachurches as the competitive advantage of scope into the paradigm of postmodernity. In the twentieth century, the organizational paradigm was the venture capitalist whose structure came with the industrial revolution. The process of secularization of society, started in the nineteenth century, placed religious organizations in the background. But the transition to the twenty-first century, the classical model of business structure declined, accompanied by the growing importance of social networks.

The research contribution contemplates dynamic interactivity in general aspects of the theory of stakeholder networks; theoretical aspects and methodological of inter cases analysis and managerial aspects of relationships in megachurches in social networks, and they can evidence in three aspects:

1. Building megachurches provides media visibility that turns into business opportunity together with other stakeholders (government, media, political groups, faithful)

On the night of July 31, at the inauguration of Solomon's Temple, politicians were prominent place. The prophetic figure of the main leader Church, Macedo, accompanied by President of the Republic, the vice president, the governor and mayor of São Paulo, looked more like a diplomatic compromise than the opening of a church (M2).

Human beings are political by nature and no organization can be considered strong if not partisan political power (P3).

In the diary, the frequency was recorded with politicians of different parties and pastors of other denominations attend the Solomon's Temple to attend the daily services.

2. The sumptuousness of Solomon's Temple as a political strategy in social networks favors the achievement of political power and institutional legitimacy as a competitive advantage factors UCKG before the competition.

Inside the temple one feels like you are in paradise. Everything is bright and beautiful. God is powerful and Solomon's temple is great (F3).

Poverty is religious delay, the more abundance, but God is pleased (P2).

The liturgy in the Temple of Solomon highlights the elements of luxury, wealth and abundance (M2).

In the field diary records show the enchantment caused by the images and luxurious details in the minds of participants quite similar services to the media shows.

3. Imitation becomes crucial element for achieving competitive advantage, since the farther the framework proposed by the UCKG, less competitive power.

Macedo created a unique style of speech imitated by other churches. challenging style, bold and determined in persuading the faithful to become imitators of these styles (P1). 
Corroborates this view, the notes made by researchers in the field diary in relation to changes of style in the words of the faithful as a kind of acculturation. Northeastern begin adopt carioca accent like a somewhat converted the identity principle.

Other data that were observed in the non-participant survey relate to seven main stakeholders that seem to express their interests in line with the intensity of the pressures that are able to exert on the degree of power, legitimacy and urgency: the federal government and the authorities, the coercive power they can exercise over the leaders of the temple; the evangelical parliamentary front, the support to the ideology of the church with 67 members elected in 2014, and members of the hierarchy, because they have sensitive information on the project that are kept secret for competing organizations.

In the perception of interviewed, the main stakeholders are the federal government and the authorities for the coercive power they can exercise over the leaders of the temple, the members of the hierarchy by secret knowledge that can possess and the evangelical parliamentary front for supporting the ideology of the church, in view of Salience Model are possessors of power, legitimacy and urgency. These two lasts are definitive stakeholders, for which managers must pay immediate attention.

From the perspective of Salience Model, the federal government and the authorities, as well as the evangelical parliamentary front and the members of the hierarchy (bishops and pastors) they are categorized as having definite stakeholder power, legitimacy and urgency for which the leaders of the Universal Church of the Kingdom of God (UCKG) must pay immediate attention.

The allied media on condition of arbitrary stakeholder, has only legitimacy, because should moderate receive attention as reinforcing strategy against competitors.

The opposing media and competitors have power and urgency, which is why they are considered dangerous stakeholders, but should not achieve legitimacy, since assume openly radically opposite to the practices of the Universal Church of the Kingdom of God (UCKG) (and often the own market religion); so these competitors, provided critical detractors (evangelical groups, but not neo-Pentecostal) and former allies detractors (usually neopentecostal) must be continuously addressed in their arguments based on scripture passages such as: "' ...being Lord of heaven and earth, dwelleth not in temples made with hands - Acts 17:24 (HOLY BIBLE, 2011).

The faithful, as dependent stakeholders, should not reach power. For this reason, the rules of conduct are strictly set for the control of the organization's internal agents. For Donaldson and Preston (1995), studies on stakeholder management can be grouped into normative aspect studies (such as the management should be), descriptive (as management is) or instrumental (which you can get to manage stakeholders). The descriptive aspect seeks to show who are the stakeholders of an organization in a given context and how their managers behave. When moving on to the Phillips (1997), critic Salience Model, can be considered evangelical parliamentary front, the combined media and the faithful as normative stakeholders, the stakeholders with whom the leaders of the Universal Church of the Kingdom of God (UCKG) establish moral obligations, while the federal government, the opposition media, critics detractors and former allies detractors are considered derivatives stakeholders that while they may achieve the organization (even being considered not legitimate group) must be designed by pragmatic legitimacy, that is, these stakeholder groups receive circumstantial and temporary treatment (favorable or unfavorable) according to the level of alignment made with the interests of the Universal Church of the Kingdom of God (UCKG) at any given time.

The non-participant observation led to the finding that the production, circulation and distribution of religious goods resulting from networks of relationships in megachurches fall within another logic, the grandeur and magnificence of the temples are efficient points 
BBR

15,3

280

of sale, a vast religious supermarket, where shepherds and missionaries play the role of marketing technicians, sales strategies experts, in line with the dictates of postmodernity.

The marketing strategy in the creation of the megachurches, while symbolic sphere of the society accompanies the transformations of the modernity, in which the life gains a new meaning to if it become dynamic and immediatist, in a change so impactful that it does not open space for the reflection, which ideology turned to the consumption (theology of the prosperity) becomes an integrant part of the social life of the individuals in which the feeling of religiosity, faith and belief acquire marketing character.

Historically, the Pentecostal movement in Brazil began to differentiate into two types, with two basic formats: Pentecostals 'classic' [(Christian Congregation of Brazil, Assembly of God, Foursquare Gospel, God is Love, The Brazil for Christ, etc. )], and the "neo-Pentecostal" [(Universal Kingdom of God, of God's Grace International, World Power of God, Ressurrection, Heal Our Land, etc.)] (PIERUCCI, 2000, p. 288). As we saw in the study categories related to megachurches item, the direct competitors neo-Pentecostal denominations of the UCKG, as WCGP the IGGC and RCC seek to build their megachurches as a way to remain competitive in this market. The first opened its megachurch in 2011, the second, plans to open its megachurch (work already started in the Bom Retiro district) in the next two years.

The RCC that does not have megachurch is secondary force before the other competitors. Prevails the imitation process in this competitive market, explains Souza (2016) competitors are urged to imitation not seem as a second-class leadership.

Build ever larger temples is a global trend, which highlights countries with Brazil and the United States. In ancient times, the great temples were signs of power and authority, now constitute, in addition to power and authority, competition factor in social networking in the symbolic religion goods market, where the marketing dispute is a way to flaunt and show power of each religious leader, since aims to conquer the same public.

Contrasting with the option for the poor of Catholicism and fundamentalism of most Pentecostal denominations, commonly, the Pentecostal entrepreneurship operates in tune as the values of contemporary society, based on competition, both economic and political, and religious. Promote the formation of various entities that bring together entrepreneurs, professionals and aspirants of various religious denominations. These organizationsevangelical provide instruction and assistance in the field of business from the perspective of Prosperity Theology. Much of these associations have contributing members and market services and artifacts. Among eases, we can highlight the / Christian Business Men's Committee of (CBMC) and Association of Full Gospel Men's Business (AFGMB), promoting the prosperity of its leaders.

In summary, the sumptuousness of megachurches provides political and media visibility that favors the commercial enterprise of the stakeholders involved. The power is not in the networks of symbolic goods market relationships of religion as absolute or as a domain of one group over the other, but as a set of controls devices on stakeholders through alliances and ruptures seeking to strengthen the position strategic organization.

The research has limitations as result to be applied in four cases studies, so it is not possible to generalize the results and conclusions obtained in the megachurches as a whole. Consequently, it is suggested further research studies in a larger sample of religious institutions, through a quantitative research on megachurches located in other regions of Brazil.

\section{REFERENCES}

AHUJA, G; SODA, G; ZAHEER, A. The genesis and dynamics of organizational networks. Organization Science, v. 23, n. 2, p. 434-448, 2012. 
AMIGO, R. New ReligiousSpaces in theMegacity:The Igreja Universal do Reino de Deus e o Templo de Salomão em São Paulo, Brazil.Zeitschriftfürjunge Religionswissenschaft,n.9, p. 5-21, 2014.

ANCONA, D.; MALONE, T. W.; ORLIKOWSKI, W. J.; SENGE, P. M. In praise of the incomplete leader. Harvard Business Review, v. 85, n. 2, p. 92-100, 2007.

BAPTISTA, S. T. C.; CAMPOS, S. M. Identidade Iurdiana em tempos líquidos: Questões sobre diferença e tradução na formação identitária da IURD. Revista de Teologia e Ciências da Religião da UNICAP, v. 3, n. 1, p. 33-62, 2013.

BAZANINI, R.Globo e Universal - tudo a ver: a disputa mercadológica pelo controle do imaginário popular ofensiva e contraofensiva retórica, Universidade Católica. 1988. Tese (Doutoramento em comunicação e semiótica) Universidade São Paulo - USP, São Paulo, 1998.

BAZANINI, R. O ensino de filosofia como um processo existencial humano. O Método Bazanini no ensino de filosofia. Filosofia aplicada à administração. São Paulo: Plêiade, 2005.

BERGER, P.; LUKMANN, T. Modernidade, Pluralismo e Crise de Sentido. Petrópolis: EditoraVozes, 2004.

BERGLER, T. E. The juvenilization of American Christianity. New York, William B. Eerdmans Publishing Company, 2012.

BIRD, W; THUMMA, S. A new decade of megachurches: 2011 profile of large attendance churches in the United States. Hartford Institute for Religion Research, 2011.

BOURDIEU, P. O podersimbólico. 6. ed. Rio de Janeiro: Bertrand Brasil, 2003.

BOURDIEU, P; MICELI, S. A economia das trocas simbólicas. São Paulo: Perspectiva, 1987.

CASTELLS, M. The rise of the network society: The information age: Economy, society, and culture. John Wiley\&Sons, 2011.

CASTELLS, M. La era de la información: economía, sociedad y cultura. siglo XXI, 2004.

CARDOSO, G; CASTELLS, M. Os media na sociedade em rede. Fundação CalousteGulbenkian, Serviço de Educação e Bolsas, 2006.

CHASSAGNON, V. Pouvoir et coop'erationdansla firme et entre les firmes. Economies ' et soci'et'es, D'eveloppement, croissance et progr'es. Paris, Presses de l'ISMEA, S'erieEconomieduTravail (AB), pp.1183-1210, 2012.

CHAVES, M. Religious organizations: Data resources and research opportunities. The American Behavioral Scientist, v. 45, n. 10, p. 1523-49, 2002.

CLARKSON, M. E. A stakeholder framework for analyzing and evaluating corporate. Socialperformance. Academy of Management Review, v.20, n.1, p. 92-117, 1995.

DA SILVA MOREIRA, A. A religião sob o domínio da estética. Horizonte, v. 13, n. 37, p. 379-405, 2015.

DE OLIVEIRA, D. de P. R. Sistemas, organização e métodos: uma abordagem gerencial. São Paulo, Atlas, 2002.

DONALDSON, T.; PRESTON, L. E. The stakeholder theory of the corporation: Concepts, Evidences and Implications. Academy of Management Review, v. 20, n. 1, 1995.

D'ORAZIO, E. (Org.). New perspectives on the stakeholder view of the firm and global corporate citizenship. NotiziediPoliteia, v. 22, n. 82, 2006.

EISENHARDT, K.M. Building theories from case study research, Academy of Management Review,v. 14, n. 4, p. 532-550, 1989.

FERRARI, O. A. Bispo S/A: A Igreja Universal do Reino de Deus e o exercício do poder. Ação Social Claretiana: Editora Ave-Maria, 2012.

FOUCAULT, M. The subject and power. Critical inquiry. The University of Chicago Press, v. 8, n. 4, p. 777$795,1982$.

FREEMAN, R. E. Strategic management: A stakeholder approach. Cambridge University Press, 2010.

FREMAN, R. E.; REED, D. L. Stockholders e stakeholders: A new perspective on corporate governance. California Management Review, v. 25, n. 3, p. 88-106, 1983.

FREEMAN, R. E.; WICKS, A.; PARMAR, B.; MCVEA, J. Stakeholder Theory: The State of the Art and Future Perspectives. In: D'ORAZIO, E. (Org.). Business ethics and corporate social responsibility in a global economy. NotiziediPoliteia, v. 20, n. 74, p. 9-22. 2004.

GOMES-CASSERES, B. Group versus group: How aliance networks compete. HawardbusinesssReview, v. 72, n. 4, p. 62-74, 1994.

GRANOVETTER, M. A Construção Social da Corrupção. Revista Política e Sociedade, n.9, p.11-37, 2006.

GULATI, R. Network Location and Learning: The Influence of Network Resources and Firm Capabilities on Alliance Formation. Strategic Management Journal, v.20, p. 397-420, 1999. 
BBR

15,3
HENNEBERG, S. C.; NAUDÉ, P.; MOUZAS, S. Sense-making and management in business networksSome observations, considerations, and a research agenda. Industrial Marketing Management, v. 39, n. 3, p. $355-360,2010$.

JADON, J.C. Sucesso e salvação-estudo semiótico comparativo entre os discursos televisivos das Igrejas Universal do Reino de Deus e Católica Apostólica Romana no Brasil. 2009 ( Doutorado em ciências Sociais) Universidade de São Paulo, São Paulo,2009.

JAWAHAR, I. M.; MCLAUGHLIN, G. L. Toward a descriptive stakeholder theory: an organizational life cycle approach. Academy of Management Review, v. 26, n. 3, p. 397-414, 2001.

HASNAS, J. Whither Stakeholder Theory?: A Guide for the Perplexed Revisited, Journal of Business Ethics,v. 112: p 47-57, 2013.

JONES, T. M. Instrumental stakeholder theory: A synthesis of ethics and economics Academy of Management Review, v. 20, n. 2, p. 404-437, 1995.

LAKATOS, E. M.; MARCONI, M. A. Metodologia do trabalho científico. $7^{\text {a }}$ ed. São Paulo: Atlas, 2007.

LIPOVETSKY, G.Era do vazio:ensaios sobre o individualismo contemporâneo. São Paulo: Manolo, 2009.

MAGALDI, W. Dinheiro, Saúde e Sagrado.2. ed., São Paulo: Eleva Cultural, , 2009

MARIANO, R. Neopentecostais: sociologia do novo pentecostalismo no Brasil. São Paulo, Loyola, 1999.

MARIOTTI, F.; DELBRIDGE, R. Overcoming network overload and redundancy in interorganizational networks: The roles of potential and latent ties. Organization Science, v. 23, n. 2, p. 511-528, 2012.

MARTINO, L. M. S. Mídia e poder simbólico: um ensaio sobre comunicação e campo religioso. São Paulo: Paulus, 2003.

MEDLIN, C. J.; TÖRNROOS, J. Interest, sensemaking and adaptive processes in emerging business networks: An Australian biofuel case. Industrial Marketing Management, v. 43, p. 1096-1107, 2014.

MIKLOS, J. Ciber-religião: a construção de vínculos religiosos na cibercultura. São Paulo: Idéias e Letras, 2012.

MILLER, K. D. Competitive strategies of religious organizations. Strategic Management Journal, v, 23, n. 5, p. 435- 456, 2002.

MITCHELL, R. K.; AGLE, B. R.; WOOD, D.J. Toward a theory of stakeholder identification and salience. Defining the principle of Who and what really counts. Academy of management review, v. 22, n. 4, p. 853-886, 1997.

MÖLLER, K. Sense-making and agenda construction in emerging business networks-How to direct radical innovation. Industrial Marketing Management, v. 39, n. 3, p. 361-371, 2010.

NOHRIA, N.; ECLES, R. Networks and organizations: Structure, form, and action. Boston: Harvard Business School, 1992.

ORTIZ, R. Mundialização:saberes e crenças. São Paulo: Brasiliense, 2006.

PAEGLE, E. G. M. A “Mcdonaldização” da fé-um estudo sobre os evangélicos brasileiros. Protestantismo em Revista, v. 17, p. 86-99, 2014.

PEREZ, L. F. Religião e sociedade de consumo. Texto apresentado no GT Fronteiras do Sagrado, na sessão Religião, mercado, consumoIn: V Reunião de Antropologia do Mercosul-Antropologias em perspectivas, 5, 2007, Florianópolis, SC,. Anais... Florianópolis, 2007.

PHILLIPS, R. Stakeholder theory and a principle of fairness.BusinessEthics Quarterly, v. 7, n. 1, p. 51-66, 1997.

PHILLIPS, R; FREEMAN, R. E., WICK S, A. C. What stakeholder theory is not. Business EthicsQuarterly, V. 13, n. 4, p. 479-502, 2003.

PRANDI, R. A realidade social das religiões no Brasil.São Paulo: Hucitec, 1996.

PRESSMAN, R. S. Engenharia de Software.3. ed. São Paulo: Pearson,Makron Books, 1995.

PROVAN, K. G.; KENIS, P. Modes of network governance: Structure, management, and effectiveness. Journal of public administration research and theory, v. 18, n. 2, p. 229-252, 2008.

RING, P. S.; VAN DE VEN, A. H. Developmental processes of cooperative interorganizational relationships. Academy of management review, v. 19, n. 1, p. 90-118, 1994.

RITZER, G.TheMcdonaldization of society. Thousand Oaks: Pine Forge Press, 1993.

ROWLEY, T. Moving beyond dyadic ties: a network theory of stakeholder influences. Academy of Management Review, v. 22, n. 4, p. 887-910, 1997.

RUTHVEN, M.; THUBRON, C. The Divine Supermarket: Travels in Search of the Soul of America. Tauris Parke Paperbacks, 2012.

SA VINHAS, A.; HEIDE, J. B.; JAP, S. D. Consistency judgments, embeddedness, and relationship outcomes in interorganizational networks. Management Science, v. 58, n. 5, p. 996-1011, 2012. 
SCHOONJANS, B.; CAUWENBERGE, P.V.; BAUWHEDE, H.V. Formal business networking and SME growth. Small Business Economics, v. 41, n. 1, p. 169-181, 2013.

SIDEBOTHAM, J. More Lessons from Unlikely Sources: When a Market Researcher and a Megachurch Meet the Episcopal Church. Anglican Theological Review, v. 97, n. 3, p. 495, 2015.

SMITH, D. A.; CAMPOS, L. S. Concentrations of Faith: Mega Churches in Brazil. A Moving Faith: Mega Churches Go South, p. 169, 2014.

SOUZA, F. (29 de fevereiro 2016). Novo megatemplo ilustra disputa de igrejas em SPpara 'mostrar poder. BBC Brasil. Disponível em: $<$ http://www.bbc.com/portuguese/noticias/2016/02/160226_megatemplos saopaulo_fs. $>$. Acesso em 05 out. 2016.

STARK, R..; BAINSBRIDGE, W. S. Teoria da religião. São Paulo: Paulinas, 2008.

STREECK, W. O cidadão como consumidor. Rio de Janeiro: Revista Piauí, n.79, p.60-65, 2013.

THE HOLY BIBLE: New InternationalVersion.Grand Rapids, MI: Zondervan, 1984.

THROUP, M. O. O Templo de Salomão em São Paulo? Sobre a ressignificação de símbolos veterotestamentários no movimento neopentecostal o DOI: http://dx. doi. org/10.15603/2176-3828/caminhando, Caminhando (online), v. 16, n. 1, p. 115-123, 2011.

THUMMA, S.; BIRD, W.Leadership Network and Hartford Institute for Religion Research/ Megachurches 2015 Report/presented by The Beck Group. Disponível em:<http://hirr.hartsem.edu/megachurch/2015 Megachurches_Report.pdf.>Acessoem: 18 set. 2016.

TICHY, N.; TUSHMAN, M.; FOMBRUN, M. Social network analysis for organizations. Academy of Management Review, v.4, n.4, p.507-519, 1979.

WALSH, J. P. Taking stock of stakeholder management. Academy of Management Review, v. 30, n.2, p. 426-438, 2005.

WEBER, M. A Ética Protestante e o Espírito do Capitalismo. São Paulo: Companhia das, 1967.

WEGNER, D.; ALIEVI, R.M.; BEGNIS, H.S.M. The life cycle of small-firm networks: an evaluation of Brazilian business networks. BAR-Brazilian Administration Review, v. 12, n. 1, p. 39-62, 2015.

ZAHEER, A.; GOZUBUYUK, R.; MILANOV, H. It's the Connections: The Networks Perspective in Interorganizational Research. The Academyof Management Perspectives, v.24, n.1, p. 62- 77, 2010.

ZANLORENCI, E. P. Descrição e qualificação de requisitos: um modelo aplicável à análise e validação da informação. 1999. Dissertação (Mestrado em Ciencias Sociais) Pontifícia Universidade Católica do Paraná, Curitiba, Parana, 1999. 